\title{
Learning of Badminton Model through Animation Video on Physical Education Students
}

\author{
Silvi Aryanti* , Hartati, Syafaruddin \\ Department of Physical Education, Faculty of Teacher Training and Education, Universitas Sriwijaya, Palembang, South Sumatra, \\ Indonesia
}

Received September 22, 2020; Revised November 24, 2020; Accepted December 22, 2020

\begin{abstract}
Cite This Paper in the following Citation Styles
(a): [1] Silvi Aryanti, Hartati, Syafaruddin, "Learning of Badminton Model through Animation Video on Physical Education Students," International Journal of Human Movement and Sports Sciences, Vol. 8, No. 6A, pp. 47-50, 2020. DOI: $10.13189 /$ saj.2020.080708.
\end{abstract}

(b): Silvi Aryanti, Hartati, Syafaruddin (2020). Learning of Badminton Model through Animation Video on Physical Education Students. International Journal of Human Movement and Sports Sciences, 8(6A), 47-50. DOI: 10.13189/saj.2020.080708.

Copyright $@ 2020$ by authors, all rights reserved. Authors agree that this article remains permanently open access under the terms of the Creative Commons Attribution License 4.0 International License

\begin{abstract}
The purpose of this study was to develop a badminton learning model through animated videos on physical education and health students of Faculty of Teacher Training and Education Universitas Sriwijaya. The media used is only in the form of images so that the use of the media is still not optimal. Furthermore, students participate in learning less actively. This research method is Research and Development. The research sample was conducted on the third semester. These steps were adapted into the following seven design research and development procedures: information gathering in the field, information analysis, early product development (draft model), expert validation, small-scale field trials and revisions, large-scale field trials and revisions, and manufacture of the final product. The data collection techniques in this research are documentation, walkthrough, questionnaire and tests. The results of research on small-scale trials conducted on 20 students obtained a percentage of 63.1, which is included in the category of "good enough" to be continued at the next stage, namely large-scale trials. The results of research on large-scale trials obtained a percentage of 82.59 , which is the average result of 55 respondents included in the "feasible" category. The finding of this research is that badminton learning model can be developed by video animation. The implication of learning this video animation based learning model can be used by students for learning badminton.
\end{abstract}

Keywords Badminton, Learning Model, Animation Video

\section{Introduction}

According Mulyasa, Education is a means to prepare present and future generations. This means that the current educational process is not solely for today, but for the future. Education is a means to strengthen national identity in the process of industrialization and encourage changes in Indonesian society in the era of globalization [10]. Rusman, The principle of organizing education is that education is held as a process of civilizing and empowering students that lasts throughout life. In the educational process required lecturers who provide role models, build will and develop the potential and creativity of students [13]. Linda, Students' success in Physical and Health Education depends largely on the learning process in which teaching method is a greater part [9].

Physical education is one of the efforts to improve human quality directed at the formation of character and personality, discipline and high sportsmanship, as well as increase achievement that can arouse a sense of national pride. Sports activities are also included in education in Indonesia. Sports activities cover a variety of branches such as athletics, games, water sports, martial arts, and so on. The aim of Physical Education is educational sports which originate from the human movement with the aim of forming human beings who can stand alone and are full of creativity and also sports can be a powerful tool for the physical and mental formation of the nation. Hartati et al, 
Physical education puts more emphasis on the development of concepts with a variety of teaching methods in accordance with the study materials taught. Physical education has an enormous relationship with science and technology [4].

One of the lecture materials for the third semester students is the deepening of the badminton sports branch with a weight of 2 credits. Students can get many benefits by playing badminton, including a good posture, anatomic, physiological, health and physical abilities. According to [2] Chandra, badminton is a small ball game with a racket and cock that is hit through the net which is stretched in the middle of the field. This game can be played by two people (single) and four people (double). Badminton rules are set by the IBF (International Badminton Federation). Therefore, it should provide appropriate learning in order to get optimal results.

The results of observations made by researchers in the semester III Physical Education study program students when learning badminton is done directly and lectures. Lecturers provide material for students and students pay attention. Therefore, learning outcomes in badminton learning are still low. This can be seen from the number of students who do not understand the basic techniques in feather play. The media used are only images so the use of the media is still not optimal. Furthermore, students participate in learning less actively. In the learning process, students are still passive; they are not focused, feel ashamed to ask questions, do not record material in the learning process, and only accept what is conveyed by the lecturer. In addition, learning activities are more centered on lecturers or one-way communication, namely from lecturers to students. Therefore, the need to use media can be motivating and fun.

Kittidachanupap, N., Singthongchai, J., Naenudorn, E., Khopolklang, N., \& Niwattanakul, S, Assimilation in use with multimedia applications and learning activities can increase children's interest during the learning process, so that it can be easier in understanding learning material [7]. The use of media in the learning process makes student learning activities more interesting and easier to understand. Therefore, in the learning process, lecturers should use the media as a tool. Djamarah, media as a tool in the learning process is a reality that cannot be denied [3]. Sumantri, the use of instructional media in the learning process can clarify the presentation of messages and information, increase and direct the students' attention and it can lead to learning motivation, and self-regulation [14]. Zin, et al, All challenges and a new strategy helps student to achieve a better understanding in a study field. Diversity in learning combinations of media such as graphics, animations, texts and graphics can certainly boost the academic level and their interest in the learning process [15].

The development of badminton learning models should meet the characteristics of students. Various forms of learning models have helped Lecturers in applying the learning process. Aryanti, based on the results of the validation of badminton game, experts obtained a percentage of $67.85 \%$ in the category of "quite feasible". Validation from experts in Physical Education, Sports and Health obtained a percentage of 69.64 in the category of "quite feasible". Long forehand service learning can be used for badminton learning [1]. Hartati, Destriana, \& Silvi, Multimedia can be used as a communication system. It is a system because it is a group of objects that relate and work together to produce a desired result. However, the Physical Education Lecturer has never developed a badminton learning model through animated video [5]. Putra, the use of videos in multimedia such as animation as learning materials for badminton techniques is very useful. This will be useful if the trainer does not have the technique or ability to give examples of movements well, then videos such as animation can be utilized [12]. The novelty of this research is that the badminton learning model is made in the form of animated videos. Material about badminton service, punches and smashes.

Based on the description above, the researchers are interested in conducting further research entitled Learning of Badminton Models through Video Animation in Physical Education Students Semester III

\section{Materials and Methods}

This research is research and development. Subject in this study were students who received physical education Faculty of Teacher Training and Education Universitas Sriwijaya in the third semester. These steps have been adapted into the following seven development research design procedures:

1) Collection of information in the field

2) Analysis of the information that has been collected

3) Initial product development (Draft Model)

4) Expert Validation

5) Small-scale field trials and revisions

6) Large-scale field trials and revisions

7) Making the final product

The planning and development phase consists of literature review and field study. The study is carried out through a literature search on learning models. The approaches are alternative multimedia, and science, technology, engineering, and mathematics (STEM), material on basic techniques of badminton. Literature is in the form of journals, dissertation and thesis research results, and handbooks. In the second stage, needs analysis was carried out by studying the resources available in the study program that is planned to be a place of research at Faculty of Teacher Training and Education Universitas Sriwijaya. In the third stage, the initial draft of the product is made. The next analysis process is the product development stage of the badminton 
learning model through video animation that can be useful and helps lecturers in learning and learning activities. The fourth stage is Expert Validation, Trial, and Improvement. Before a small-scale trial of the initial product is carried out, the product must be validated by material experts, namely: (a) material expert (b) media expert, and (c) and linguist. The validation process is expected to give input on the initial product. In the next stage, a small-scale field trial is carried out to see the extent to which the product can be used; after the small-scale trial phase, a product revision is carried out. Product revisions are made after expert input and the results of small-scale trials.

The next stage after the product revision is the second stage of validation. This validation is intended to see products that have been tested and revised. The next stage is large-scale trials and revisions. In the final stage, the final product is ready to be tested for its effectiveness.

\section{Result and Discussion}

The needs analysis of this research aims to determine the problems that occur in the field. This relates to the multimedia model in badminton courses. Theoretical material when implementing learning is not optimal because the learning media do not yet support. Based on the existing problems in the field, it was developed using animated videos that can improve badminton learning outcomes of the third-semester students. The focus of developing a multimedia model is to improve badminton learning outcomes.

Small-scale trials are a step in research and development. The aim of small-scale trials is to find out the extent to which the effectiveness of the video animation-based badminton learning model is developed. Small-scale trial respondents were 20 students. The results of trials on a small scale about the development of learning models based on video animation badminton courses obtained a percentage of 63.1 which is the average result of 20 respondents who have been tested. The trial results obtained by $63.1 \%$ are included in the category of "reasonable enough" to be continued at the next stage.

Large-scale trials are conducted after the second phase of revision. The purpose of large-scale trials conducted is to determine the extent to which multimedia-based video animation can be used in basketball learning. The test was conducted on 55 students. Respondents in this study were students of Physical Education Faculty of Teacher Training and Education Universitas Sriwijaya. The results of the study on a large-scale trial development of learning models based on video animation in badminton subjects obtained a percentage of 82.59. Results of trials on a large scale of $82.59 \%$ included in the category of "feasible" are used as multimedia. Multimedia learning based on video animation badminton courses can be said to be a product of development.
Based on research conducted by Nishihara, Y., \& Yonemura, $\mathrm{K}$, the results of this study suggest the possibility of perceiving the teaching materials, objectives, content, students, and the setting as an integral whole. Video annotation also enabled the teachers to grasp the difference in difficulty between clarifying concrete teaching problems and actually improving those problems to achieve results in daily classes [11]. Kok, M., Komen, A., van Capelleveen, L., \& van der Kamp, J, Self-controlled video feedback without guidance of a teacher on movement technique led to similar learning effects as traditional guidance of the teacher in a Physical Education context. Self-control of feedback delivery (i.e. timing and frequency) seemed to have positive effects on self-efficacy and perceived learning effect, but did not lead to superior motor learning or perceived enjoyment. This study indicates that self-controlled video feedback as applied in this study can be implemented in Physical Education [8]. Ho, L. H., Sun, H., \& Tsai, T. H., as well as motion graphic animation video media, its effectiveness has been tested in improving students' achievement, especially the experimental group. Hence, the interactive motion graphic media is effective in improving the students' knowledge in the science subject of the fifth graders [6].

The research product in the form of an animated video is suitable for learning badminton games. There are various kinds of learning models for basic badminton techniques such as serves, punches, and smashes It can help students understand the basic techniques of badminton games. The use of animated video-based badminton learning models can be used by students. This can assist students in understanding the techniques in badminton. The animated video presented varies; the instructions are clear and there are examples of how to implement.

\section{Conclusions}

Advances in information and communication technology, especially computer technology in learning activities are expected to help solve the learning problems encountered. The selection of the right learning media can help convey the message correctly, effectively and efficiently. Based on the results of a small-scale trial conducted on 20 Faculty of Teacher Training and Education Universitas Sriwijaya Physical Education students, a percentage of 63.1 was included in the "feasible" category to be continued at the next stage, namely a large-scale trial. The results of a large-scale trial of developing multimedia subjects in work (basketball) that is 82.59 is the average result of 55 respondents included in the "feasible" category. This shows that it can be used as multimedia. Multimedia based video animation in badminton courses can be said to be a multimedia development product. The research product in the form of 
a learning model with animated videos can be recommended for lecturers in teaching, and can be used by coaches to train badminton athletes.

\section{Acknowledgments}

I would like to extend my gratitude to the Dean of Faculty of Teacher Training and Education Universitas Sriwijaya for facilitating competitive research grants, and students who have participated in the badminton learning.

\section{REFERENCES}

[1] Aryanti, S., Victorian, A. and Yusfi, H. (2018) "PENGEMBANGAN TEKNIK PEMBELAJARAN SERVIS FOREHAND BULUTANGKIS BAGI SISWA PUTRA SEKOLAH MENENGAH ATAS”, Sebatik, 22(2), pp. 181-187. Available at: http://jurnal.wicida.ac.id/index.p hp/sebatik/article/view/325 (Accessed: 21October2019).

[2] Chandra, Sodikin. 2010. Pendidikan Jasmani Olahraga dan Kesehatan. Jakarta: Departemen Pendidikan Nasional.

[3] Djamarah, Syaiful Bahri dan Zain, Aswan. 2010. Strategi Belajar Mengajar.Jakarta: Rineka Cipta.

[4] Hartati, H., Destriana, D., Aryanti, S., \& Destriani, D. (2018, September). Macro Flash-based Multimedia for Improvement the Learning Result of Volleyball Game. In International Conference on Teacher Training and Education 2018 (ICTTE 2018). Atlantis Press.

[5] Hartati, H., Destriana, D., \& Aryanti, S. (2016, September). Multimedia Development on Sports Health Subject for Third Semester Students Of Penjaskes Fkip Unsri. In Sriwijaya University Learning and Education International Conference (Vol. 2, No. 1, Pp. 469-484).

[6] Ho, L. H., Sun, H., \& Tsai, T. H. (2019). Research on 3D Painting in Virtual Reality to Improve Students' Motivation of 3D Animation Learning. Sustainability, 11(6), 1605.
[7] Kittidachanupap, N., Singthongchai, J., Naenudorn, E., Khopolklang, N., \& Niwattanakul, S 2012 Development of Animation Media for Learning English Vocabulary for Children. In International Conference on Computer Science and Automation Engineering (CSAE) pp. 341-345 http://dx.doi.org/10.1109/CSAE.2012.6272788

[8] Kok, M., Komen, A., van Capelleveen, L., \& van der Kamp, J. (2020). The effects of self-controlled video feedback on motor learning and self-efficacy in a Physical Education setting: an exploratory study on the shot-put. Physical Education and Sport Pedagogy, 25(1), 49-66.

[9] Linda N. Chukwurah, Oliver I. Abbah, Cylia N. Iweama, John E. Ogugua, Jonathan Ameh. (2020). Students' Achievement in Physical and Health Education: Effect of Discussion Teaching Method. International Journal of Human Movement and Sports Sciences, 8(3), 86-90.

[10] Mulyasa. 2010. Kurikulum Tingkat Satuan Pendidikan. Bandung: Remaja Rosdakarya.

[11] Nishihara, Y., \& Yonemura, K. (2018). An Attempt to Improve Cooperative Learning by Physical Education Teachers Using a Video Annotation System. International Journal of Sport and Health Science, 201803.

[12] Putra, Ghazali Indra. 2016. Pengembangan Pembelajaran Teknik Dasar Bulu Tangkis Berbasis Multimedia Pada Atlet Usia 11 Dan 12 Tahun. Program Studi Ilmu Keolahragaan, Program Pascasarjana, Universitas Negeri Yogyakarta. Jurnal Keolahragaan, Print ISSN: 2339-0662, Online ISSN: 2461-0259

[13] Rusman. 2013. Model-model Pembelajaran Mengembangan Profesionalisme Guru. Jakarta: Grafindo.

[14] Sumantri, M. S., \& Rachmadtullah, R. (2016). The effect of learning media and self-regulation to elementary students' history learning outcome. Advanced Science Letters, 22(12), 4104-4108.

[15] Zin, M. Z. M., Sakat, A. A., Ahmad, N. A., \& Bhari, A. (2013). Relationship between the multimedia technology and education in improving learning quality. Procedia-Soci al and Behavioral Sciences, 90, 351-355. 